\title{
The relative involvement of Th1 and Th2 associated immune responses in the expulsion of a primary infection of Heligmosomoides polygyrus in mice of differing response phenotype
}

\author{
A. Ben-Smith ${ }^{1}$, D.A. Lammas ${ }^{2 *}$ and ${ }^{*}$ J.M. Behnke \\ ${ }^{1}$ Karonga Prevention Study, PO Box 46, Chilumba, Malawi: ${ }^{2}$ Division of \\ Immunity and Infection, The Medical School, University of Birmingham, \\ B15 2TT, UK: ${ }^{3}$ School of Life and Environmental Sciences, University of \\ Nottingham, Nottingham, NG7 2RD, UK
}

\begin{abstract}
T helper cell (Th1 and Th2) associated responses were examined following a primary infection with the gastrointestinal nematode Heligmosomoides polygyrus in five inbred strains of mice with different resistance phenotypes. Levels of (i) mast cell protease, (ii) specific IgE, (iii) nitric oxide and (iv) specific IgG2a, as markers of Th2 and Th1 associated responses, respectively, were determined in sera and intestinal fluids and correlated with worm burdens. The 'fast' responder (resistant) strains SWR and SJL produced strong Th2 and Th1 associated responses respectively in a mutually exclusive fashion. The $\mathrm{F}_{1}$ hybrid $(\mathrm{SWR} \times \mathrm{SJL}) \mathrm{F}_{1}$, showed rapid expulsion of the parasite and expressed both intense Th1 and Th2 responses, suggesting synergism between Th1 and Th2 activity in these mice. The results indicate that both Th2 and Th1 responses operate in mice following a primary infection with H. polygyrus and that each Th response may be involved to a greater or lesser degree within certain strains. Resistance to $H$. polygyrus was found to correlate only to the intensity of either the gut-associated mastocytosis or nitric oxide production in these strains but not to either specific IgE or IgG2a titres. Chronic infections in the 'slow' response phenotype mouse strains CBA and C57BL/10, were associated with both poor Th2 and poor Th1-associated responses attributed to a general parasite-mediated immunosuppression of the host immune response to infection.
\end{abstract}

\section{Introduction}

A major advance in our understanding of the regulation of host immune response(s) to parasitic infections, particularly in murine model systems, has been the division of $\mathrm{CD}^{+}$lymphocytes into distinct $\mathrm{T}$ helper cell subsets (Th1 and Th2) based upon cytokine production

*Author for correspondence

Fax: (+44) 1214143599

E-mail: D.A.Lammas@Bham.ac.uk
(Mosmann \& Coffman, 1989). Th1 and Th2 cells are thought in mice to act in a reciprocal manner, being mutually inhibitory and/or self-stimulatory in action (Mossman \& Moore, 1991). We postulate that there are two pathways, regulated by distinct CD4+ Th cell populations that lead to activation of mechanisms responsible for the elimination of parasitic helminth infections.

The first, via Th2 cells, is characterized by an acute immediate hypersensitivity type inflammatory response associated with a mucosal mastocytosis (regulated by a combination of interleukin(IL)-3, IL-4, IL-9 and IL-10 
(Urban et al., 1992)), eosinophilia (dependent on IL-3 and IL-5 (Coffman et al., 1989)) mucus secretion by goblet cells (dependent on IL-13 (Bancroft et al., 1998; Artis et al., 1999)), intestinal epithelial cell function (mediated by IL-4 and IL-13 (Shea-Donohue et al., 2001)) and specific IgE production (via IL-4 modulation of B cell isotype switching (Finkelman et al., 1990)).

A second mechanism, associated with the Th1 arm of the immune response, is characterized by a delayedtype hypersensitivity(DTH)/cell-mediated immune(CMI) reaction, involving macrophage activation, (with release of reactive nitrogen and oxygen intermediates), cytotoxic $\mathrm{T}$ cells, and NK cell antibody-dependent cytotoxicity (regulated by interferon (IFN)- $\gamma$, IL-2, IL-12, tumour necrosis factor (TNF)- $\alpha$ and TNF- $\beta$ ), increased epithelial cell turnover (dependent on IFN- $\gamma$ (Bancroft et al., 1998; Artis et al., 1999)), and specific IgG2a production (mediated via IFN- $\gamma$ inhibition of IL-4 induced switching, and induction of switching to $\gamma 2 a$ (Romagnani, 1992)). Such CMI responses however have traditionally been thought to be restricted to immunity to intracellular parasites and to viral and bacterial infections (Liew et al., 1989) or alternatively associated with DTH-associated immunopathology (Garside et al., 2000).

One current hypothesis advocates that expulsion of gastrointestinal nematodes such as Trichinella spiralis, Nippostrongylus brasiliensis, and Haemonchus contortus occurs via a Th2-associated allergic inflammatory response, supported mainly by evidence based upon the correlation between mastocytosis and mast cell proteases levels and worm expulsion, observed in mice of differing response phenotype (Nawa \& Miller, 1979; Alizadeh \& Wakelin, 1982; Tuohy et al., 1990; Gill et al., 1992; Grencis et al., 1993). The allergic inflammatory response per se, however, is not thought to irreversibly damage or kill the infecting parasite, as expelled T. spiralis, Strongyloides ratti and $N$. brasiliensis adult worms have been shown to be capable of survival if surgically transplanted into the intestines of naïve animals (Rothwell, 1989).

Therefore, in response to gastrointestinal infections, both (Th1 and Th2 mediated) immune mechanisms could in theory result in a similar outcome, i.e. the generation of an immunologically non-specific inflammatory response following stimulation by a specific antigen/T-cell interaction. Indeed, both arms of the $\mathrm{T}$ cell response are thought to be initiated in the early stages of most helminth infections. Subsequently the response may be biased in favour of Th1 or Th2-type responses depending on the infection and the genetic makeup of the host (Nakamura et al., 1997). The inflammation elicited by either system could make the intestine an unsuitable environment for the persistence of the worms, resulting in their expulsion (Wakelin, 1993). However, the main cellular and humoral effector molecules associated with the two $\mathrm{T}$ helper cell pathways are distinct.

Although data obtained from studies using both IL-4 knockout and IL-4 treated mice clearly illustrate the importance of this Th2-associated cytokine in the regulation of resistance and susceptibility to $H$. polygyrus infection (reviewed in Finkelman et al., 1997), the specific effector mechanism(s) mediating worm expulsion remain unresolved. There is also a paradox in that $H$. polygyrus worm expulsion apparently occurs in the absence of a Th2-associated intestinal mastocytosis (Dehlawi \& Wakelin, 1988). Similarly, mast cell deficient $\mathrm{W} / \mathrm{W}^{\mathrm{v}}$ mice have been reported to develop the same level of protective immunity as wild type litter mates to infection with $H$. polygyrus (Urban et al., 1992) and neutralization of IgE production was not found to inhibit protective immunity in infected mice (Urban et al., 1991). Moreover, in certain 'resistant' strains of inbred mice, such as SJL, $H$. polygyrus adult worms were rapidly expelled in the absence of either a marked mast cell or specific IgE response (Tuohy, 1992) suggesting that another mechanism(s) operates to remove the parasite in this strain.

In this study, the relative importance of both Th1- and Th2-associated immune responses were assessed following a primary infection with $H$. polygyrus within selected 'rapid' (SWR $\times \mathrm{SJL}) \mathrm{F}_{1}$, 'fast', (SJL and SWR), 'intermediate' $(\mathrm{NIH})$, and 'slow' (CBA and C57BL/10) responder strains of inbred mice in terms of their worm expulsion phenotype (table 1).

Strain-dependent differences in the intensity and kinetics of release of mucosal mast cell protease and parasite-specific IgE responses (as markers of a Th2associated inflammatory response) and parasite-specific IgG2a and nitric oxide (NO) responses (as indicators of a Th1-associated CMI response) were then evaluated for positive associations with worm expulsion to help provide an insight into the effector mechanism(s) responsible for this phenomenon.

\section{Materials and methods}

\section{Animals}

Female syngeneic NIH, C57BL/10, CBA/Ca, BALB/c SWR, SJL and $\left(S W R \times S_{L}\right) F_{1}$ hybrid mice were either purchased from Harlan Olac Ltd (Bicester, Oxon) as specific pathogen free, or were bred in the departmental animal unit. All the animals were used at approximately 8-10 weeks of age and maintained under conventional conditions with food and water provided ad libitum. A minimum of five mice per group was used in each experiment.

\section{Heligmosomoides polygyrus}

The parasite used was Heligmosomoides polygyrus bakeri (Behnke \& Wahid, 1991). The methods used for maintenance and infection of mice and recovery of adult worms at autopsy were essentially as described by Jenkins \& Behnke (1977).

\section{Heligmosomoides polygyrus excretory/secretory (E/S) products antigen preparation}

Adult worms were recovered from outbred CFLP mice infected 14 days earlier with 400-600 L3 of H. polygyrus. The parasites were washed in sterile phosphate buffered saline and cultured aseptically for $24 \mathrm{~h}$ at $37^{\circ} \mathrm{C}$ in RPMI 1640 medium (Gibco) supplemented with $0.1 \mathrm{~mm}$ sodium 
Table 1. Resistance ranking of inbred strains of mice to a primary infection with Heligmosomoides polygyrus.

\begin{tabular}{|c|c|c|c|c|}
\hline Strain haplotype & H-2 genes & $\begin{array}{l}\text { Background } \\
\text { genes }\end{array}$ & $\begin{array}{l}\text { Immunity } \\
\text { to infection }\end{array}$ & $\begin{array}{l}\text { Responder } \\
\text { status }\end{array}$ \\
\hline CBA & $\mathrm{k}$ & CBA & - & Slow \\
\hline $\mathrm{C} 3 \mathrm{H}$ & $\mathrm{k}$ & $\mathrm{C} 3 \mathrm{H}$ & - & Slow \\
\hline C57BL/10 & $\mathrm{b}$ & B10 & - & Slow \\
\hline B10G & $q$ & B10 & - & Slow \\
\hline B10S & $\mathrm{s}$ & B10 & + & Intermediate \\
\hline $\mathrm{B} 10 \mathrm{D} 2 / \mathrm{n}$ & d & B10 & + & Intermediate \\
\hline $\mathrm{BALB} / \mathrm{c}$ & d & BALB & + & Intermediate \\
\hline $\mathrm{NIH}$ & $\mathrm{q}$ & NIH & + & Intermediate \\
\hline $\mathrm{DBA} / 1$ & $\mathrm{q}$ & DBA $/ 1$ & + & Intermediate \\
\hline $\mathrm{DBA} / 2$ & $\mathrm{~d}$ & $\mathrm{DBA} / 2$ & + & Intermediate \\
\hline$(\mathrm{NIH} \times \mathrm{C} 57 \mathrm{BL} 10) \mathrm{F}_{1}$ & $\mathrm{bq}$ & $\mathrm{NIH} / \mathrm{B} 10$ & + & Intermediate \\
\hline$(\mathrm{NIH} \times \mathrm{B} 10 \mathrm{G}) \mathrm{F}_{1}$ & $q$ & $\mathrm{NIH} / \mathrm{B} 10$ & + & Intermediate \\
\hline SWR & $\mathrm{q}$ & SWR & ++ & Rapid \\
\hline SJL & $\mathrm{s}$ & SJL & ++ & Rapid \\
\hline$(\mathrm{SWR} \times \mathrm{SJL}) \mathrm{F}_{1}$ & qs & SWR/SJL & +++ & Extremely rapid \\
\hline
\end{tabular}

The relative ranking of the strains was arranged on the basis of the data in Behnke \& Robinson (1985) and on experiments conducted over recent years. The responder status, assessed on the basis of time to loss of adult worms following primary exposure, varies from experiment to experiment, but despite this, inter-experiment variation, the relative ranking of the strains remains constant. - slow or very weak; + , intermediate; ++ , rapid; +++ , extremely rapid and strong.

pyruvate (Sigma, UK), $100 \mathrm{U} \mathrm{ml}^{-1}$ penicillin +100 $\mu \mathrm{g} \mathrm{ml}^{-1}$ streptomycin solution (Gibco), $75 \mu \mathrm{M}$ monothiolglycerol (Sigma) and 10\% foetal calf serum (Gibco). The supernatant was filtered through a $0.22 \mu \mathrm{m}$ filter (Millipore, UK), dialysed $(22 / 35 \mathrm{kDa}$ dialysis tubing) against distilled water for $24 \mathrm{~h}$ at $4^{\circ} \mathrm{C}$, lyophilized and resuspended in a smaller volume. The sample was analysed for protein using the Bio-Rad protein assay kit (Bio-Rad, UK) and stored at $-40^{\circ} \mathrm{C}$.

\section{Serum collection}

Mice were killed with an overdose of ether, their thoracic cavities opened and their hearts punctured. The blood that accumulated in the cavity was collected into $1.5 \mathrm{ml}$ Eppendorf tubes containing $50 \mu \mathrm{l}$ of Serasieve gel (Hughes and Hughes Ltd), allowed to clot and spun at $13,000 \mathrm{~g}$ for $5 \mathrm{~min}$. The resulting serum was then removed and stored at $-40^{\circ} \mathrm{C}$.

\section{Intestinal lavage}

Intestinal secretions were collected by a modification of the method of Elson et al. (1984). Mice were killed and the small intestine removed. Three $\mathrm{ml}$ of a solution of $0.1 \mathrm{mg} \mathrm{ml}^{-1}$ soybean trypsin-chymotrypsin inhibitor (Sigma) in $50 \mathrm{~mm}$ ethylenediaminetetracetic acid (EDTA, Sigma) was flushed through the intestine, which was then massaged gently to ensure maximal recovery of the inhibitor. The samples were vortexed and centrifuged at $650 \mathrm{~g}$ for $10 \mathrm{~min}$. Thirty microlitres of $100 \mathrm{~mm}$ phenylmethylsulphonyl fluoride (PMSF, Sigma) in 95\% ethanol was added to the supernatants, and the samples further clarified by centrifugation at $27,000 \mathrm{~g}$ at $4^{\circ} \mathrm{C}$ for $20 \mathrm{~min}$. Twenty microlitres of PMSF and $20 \mu \mathrm{l}$ of $1 \%$ sodium azide (Sigma) were added to the supernatant, which was left to stand for $15 \mathrm{~min}$ before $100 \mu \mathrm{l}$ foetal calf serum (Gibco) was added; this was added to provide an alternative substrate for any remaining protease in the intestinal secretion. The samples were stored at $-40^{\circ} \mathrm{C}$ until used.

\section{Measurement of H. polygyrus-specific IgG2a and IgE responses}

Standard ELISA assays were used to assess the levels of parasite-specific (E/S products) IgG2a and IgE antibody responses in serum and intestinal fluid samples essentially as described by Wahid \& Behnke (1993). Mouse samples were assayed individually; serum was tested at a dilution of 1:50 and intestinal samples were used undiluted. Each plate included control 'hyper-immune' serum (HIS), (Behnke \& Parish, 1979) and also serum from naive mice (NS). With regard to IgE levels, the optical density (OD) for each sample minus the OD of the NS was expressed as a percentage of the OD of the HIS minus the NS, giving a relative response index (RRI). Both serum and luminal IgG2a results, however, are presented as OD values, as the intestinal samples contained more IgG2a than the HIS samples, which led to very high RRI values, so that small changes in OD values gave very large differences in the corresponding RRI values. Nevertheless, the pattern of response was found to be similar whichever way the results were expressed. Results are presented as mean RRI or OD value \pm standard error (SEM) for each group.

\section{Measurement of mucosal mast cell protease (MMCP-1)}

The levels of MMCP-I present in serum and intestinal fluid were measured using an antigen-capture ELISA technique as described by Huntley et al. (1990). The reagents were provided as a kit from Moredun Animal Health Ltd, Edinburgh. Values of MMCP-I in serum were expressed as mean $\mu \mathrm{g} \mathrm{ml}^{-1}$ and in intestinal fluid as mean $\mu \mathrm{g} \mathrm{mg}^{-1}$ protein \pm standard error (SEM) for each group. 


\section{Measurement of nitric oxide (Greiss reagent)}

The Griess reaction assay as described by Green et al. (1982) was used to assay for nitrite in both intestinal fluids and in serum; however, as serum contains greater amounts of nitrate than nitrite, the nitrate was first converted to nitrite using a nitrate reductase reaction. All solutions were made up in double-deionized (nitratefree) water. Results are expressed as mean levels $(\mu \mathrm{M})$ of nitrite \pm standard error (SEM) for each group.

\section{Conversion of serum nitrate to nitrite}

Equal volumes of serum were incubated with a reaction mixture which consisted of equal proportions of: NADPH, $5 \mathrm{mg} \mathrm{ml}^{-1}$, FAD, $41.5 \mathrm{mg} \mathrm{ml}^{-1}, \mathrm{KH}_{2} \mathrm{PO}_{4}$ ， $50 \mathrm{~mm}$, Aspergillus nitrate reductase, $3.4 \mathrm{mg} \mathrm{ml}^{-1}$ and distilled water. The serum mix was then incubated at $37^{\circ} \mathrm{C}$ for $2-4 \mathrm{~h}$ prior to assessment in the nitrite (Greiss reaction) assay.

\section{Experimental design}

Three sets of experiments were undertaken to examine the relationship between host resistance, as determined by worm expulsion, and Th1/Th2-mediated immune responses elicited in selected mouse strains following a primary infection with $H$. polygyrus in terms of mucosal mast cell protease (MMCP-I) release, specific $\mathrm{IgE}$ and IgG2a responses and NO release in serum and intestinal fluids.

The experiments were carried out using the following combinations of mouse strains: experiment $1, \mathrm{CBA}, \mathrm{NIH}$ and SWR infected with 50 L3 larvae; experiment 2, C57BL/10, SWR and $\left(S W R \times \mathrm{SJL}_{\text {) }}\right.$ infected with $100 \mathrm{~L} 3$ larvae; experiment 3 , SWR, SJL and $(\mathrm{SWR} \times \mathrm{SJL}) \mathrm{F}_{1}$ infected with 50 L3 larvae. The infection dosage used for each experiment was dictated primarily by L3 recovery yields. However, we have previously reported that worm burdens resulting from doses of 50-100 L3 are rejected in the same time frame by these strains of mice (Wahid et al., 1989). Comparison of the results from these three sets of experiments were then justified by the fact that they would not be predicted to alter either worm expulsion kinetics or the intensity of the immune parameters obtained.

\section{Statistical analysis}

Worm burden data sets were analysed using GLIM (Healy, 1988; Crawley, 1993) and conducted with negative binomial errors and hence these results are indicated as chi squares $\left(\chi^{2}\right)$, degrees of freedom $(d f)$ and probability values $(P)$. A probability of $P \leq 0.05$ was considered significant and $P>0.05$ was recorded as not significant (NS).

In the case of the parasite-specific antibody, MMCP-I and NO data, each set was tested for normality using a normal probability plot and then subjected to an analysis of variance using the general linear model (GLM) to assess the effects of time, strain and the interaction between time and strain (Ryan et al., 1985) with respect to time and strain. Hence, results are indicated as $F$ values, degrees of freedom $(d f)$ and probability values $(P)$. A probability of $P \leq 0.05$ was considered to be significant. Results are shown as mean values \pm standard errors of means (SEM). The baseline on each graph represents the values obtained for naive animals, therefore the values presented graphically are those for the infected minus naïve animals.

\section{Results}

Experiment 1: fast, intermediate and slow expelling infections

Three strains of mice representing 'fast' (SWR), 'intermediate' (NIH) and 'slow' (CBA) responder phenotypes were examined for their immune response phenotype to a $H$. polygyrus primary infection. The worm recoveries over the time course of the experiment are shown in fig. 1a. All three strains examined expelled true to their predicted phenotype ranges, i.e. SWR mice rapidly expelled their worms between weeks 4-6 p.i., NIH between weeks 6-10 p.i. and CBA mice maintained their burdens over the 10 weeks examined, with significant differences seen with respect to both the mouse strain and the timing of expulsion (strain: $\chi^{2}=14$, $d f=2, P<0.001$; time: $\left.\chi^{2}=82, d f=3, P<0.001\right)$.

Both serum and luminal MMCP-I levels declined in all three strains from peak values at week 2 over the subsequent $6-10$ weeks p.i. With regard to serum MMCP1 levels (fig. 1b), in the slow responder strain (CBA) these were significantly lower than those detected in the other two responder strains of mice at weeks 6 and 10 p.i. $(F=7, \quad d f=2, \quad P=0.002$; week 6: CBA $0.46 \pm$ $0.04 \mu \mathrm{g} \mathrm{ml}^{-1}$, NIH $0.94 \pm 0.08 \mu \mathrm{g} \mathrm{ml}^{-1}$, SWR $0.81 \pm$ $0.05 \mu \mathrm{g} \mathrm{ml}^{-1}$; week 10: CBA $0.54 \pm 0.1 \mu \mathrm{g} \mathrm{ml}^{-1}$, NIH $0.66 \pm 0.04 \mu \mathrm{g} \mathrm{ml}^{-1}$, SWR $0.87 \pm 0.09 \mu \mathrm{g} \mathrm{ml}^{-1}$ ). There was also a significant difference in the kinetics of production of serum MMCP-I between the three strains of mice $(F=69, d f=2, P<0.001)$. However, there was no significant difference in the levels of MMCP-I between any of the three strains examined in the intestinal fluids (fig. 1c; week 2: $0.21 \pm 0.04 \mu \mathrm{g} \mathrm{mg}^{-1}$ protein (CBA) to $0.28 \pm 0.01 \mu \mathrm{g} \mathrm{mg}^{-1}$ protein (SWR); week 10: $0.05 \pm$ $0.01 \mu \mathrm{g} \mathrm{mg}^{-1}$ protein (CBA and $\mathrm{NIH}$ ) to $0.06 \pm 0.01$ $\mu \mathrm{g} \mathrm{mg}^{-1}$ protein (SWR)).

IgE levels in both serum and gut increased throughout the infection in all the three strains examined. However, both the 'fast' responder (SWR) and the 'intermediate' responder (NIH) mice produced significantly greater levels of serum IgE with faster kinetics than the 'slow' responder (CBA) mice at weeks 6 (RRI of $90.5 \pm 11.77$ in SWR and $51.26 \pm 11.73$ in NIH, compared to $0.59 \pm 11.0$ in CBA) and 10 p.i. (RRI of $142.13 \pm 7.77$ in SWR and $98.72 \pm 9.5$ in $\mathrm{NIH}$, compared to $24.36 \pm 7.87$ in CBA) (fig. 1d, strain: $F=38, d f=2, P<0.001$; time: $F=56$, $d f=3, P<0.001)$. This pattern of higher and more rapid IgE responses in the 'fast' and 'intermediate' responder strains than observed in the slow responder strain was mirrored in the intestine (week 6 p.i., RRI of $234.23 \pm$ 42.52 in SWR, $232.82 \pm 40.54$ in NIH, $54.45 \pm 35.31$ in CBA; week 10 p.i., RRI of $240.88 \pm 46.34$ in SWR, $253.49 \pm$ 50.45 in NIH, $107.81 \pm 26.94$ in CBA; fig. 1e).

Low levels of parasite-specific IgG2a (as measured by OD units) were detected in the serum of all three 

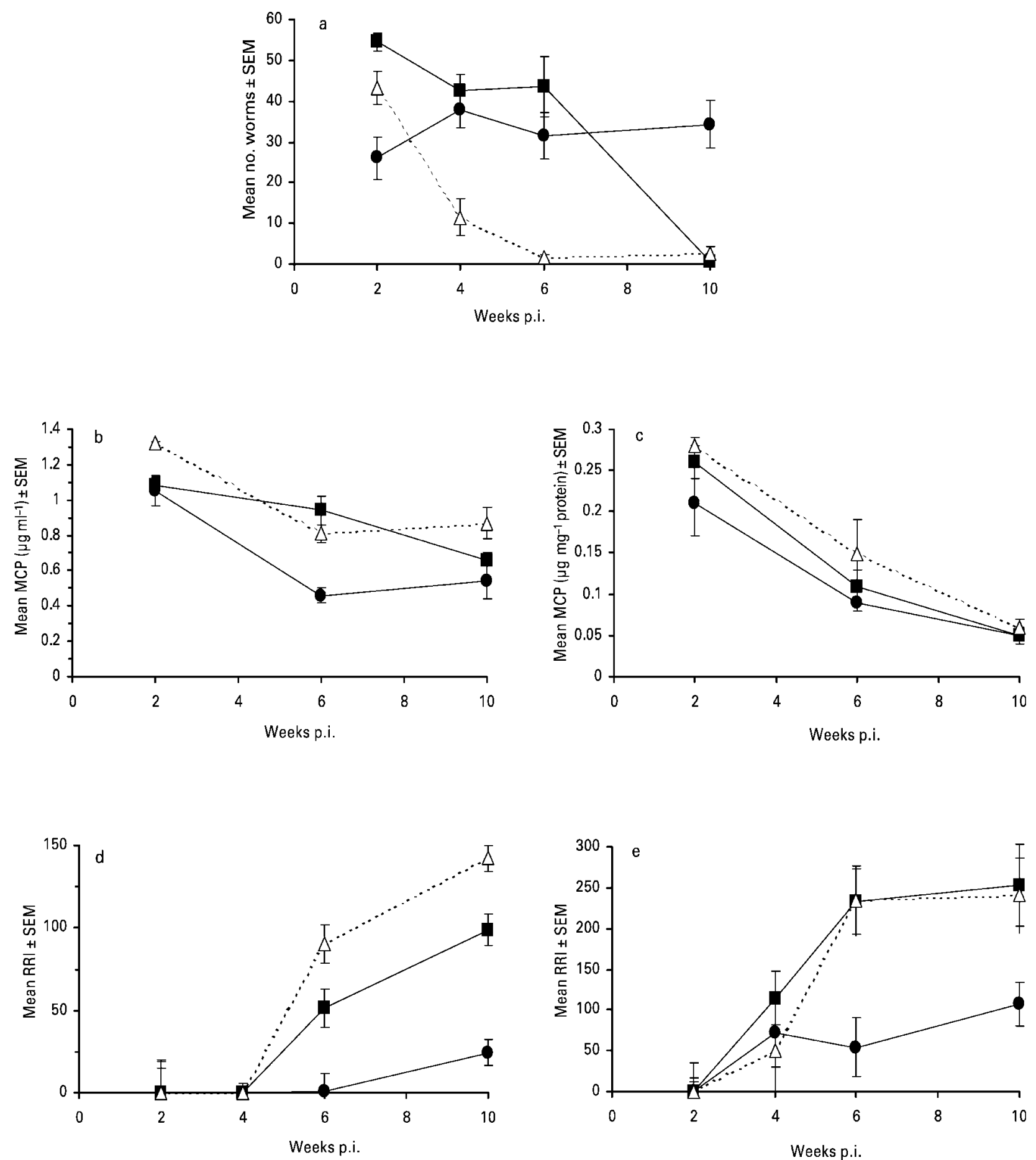

Fig. 1. Experiment 1. Worm burdens (a), serum (b) and intestinal (c) MMCP-I levels and parasite-specific serum (d) and intestinal (e) IgE in 'fast' responder $($ SWR $\triangle$ ), 'intermediate' responder (NIH $\mathbf{a})$ and 'slow' responder (CBA $\bullet$ ) strains of mice after a primary infection with $50 \mathrm{~L} 3$ larvae of Heligmosomoides polygyrus. MMCP-I levels are expressed as mean values ( $\mu \mathrm{g} \mathrm{ml}^{-1}$ (serum) or $\mu \mathrm{g} \mathrm{mg}{ }^{-1}$ protein (intestine)) of the infected minus naïve animals; IgE levels are expressed as mean index relative to naïve and hyper-immune serum (RRI, see methods) of infected minus naïve animals. 
strains of mice; however, NIH mice produced significantly more IgG2a than the other two strains at week 10 p.i. (fig. $2 a$; strain: $F=46, d f=2, P<0.001$; time: $F=86, d f=3, P<0.001)$. In intestinal samples, relatively high levels of IgG2a (as measured by OD units) were detected in all three strains of mice compared to levels in the serum, suggesting local production of this antibody isotype (fig. 2b). Greatest IgG2a levels were produced by the SWR mice in a biphasic response, peaking at weeks $4(0.79 \pm 0.08 \mathrm{OD}$ units) and 10 p.i. (0.76 $\pm 0.10 \mathrm{OD}$ units) respectively. $\mathrm{NIH}$ levels, already elevated at week 2 p.i. $(0.29 \pm 0.09$ OD units), peaked at week 4 p.i. (0.40 \pm 0.03 OD units) before falling to control values by week 6 p.i. By comparison, in CBA mice, intestinal levels of IgG2a rose steadily from basal levels at week 2 p.i., peaking at week 6 p.i. $(0.30 \pm 0.08 \mathrm{OD}$ units $)$ and then declining slightly by week 10 p.i. (0.14 \pm 0.03 OD units) (fig. 2b).

Analysis of serum samples from the three strains of mice for the presence of nitrite showed that levels in all three strains rose rapidly after week 2 p.i. to peak at week 6 p.i. for SWR (week 2, $0 \pm 2.02 \mu \mathrm{M}$; week 6, $15.29 \pm 1.38 \mu \mathrm{M}$ ) and $\mathrm{NIH}$ (week 2, $0 \pm 2.6 \mu \mathrm{M}$; week 6 , $13.38 \pm 2.21 \mu \mathrm{M}$ ) mice and at week 10 for CBA mice (week
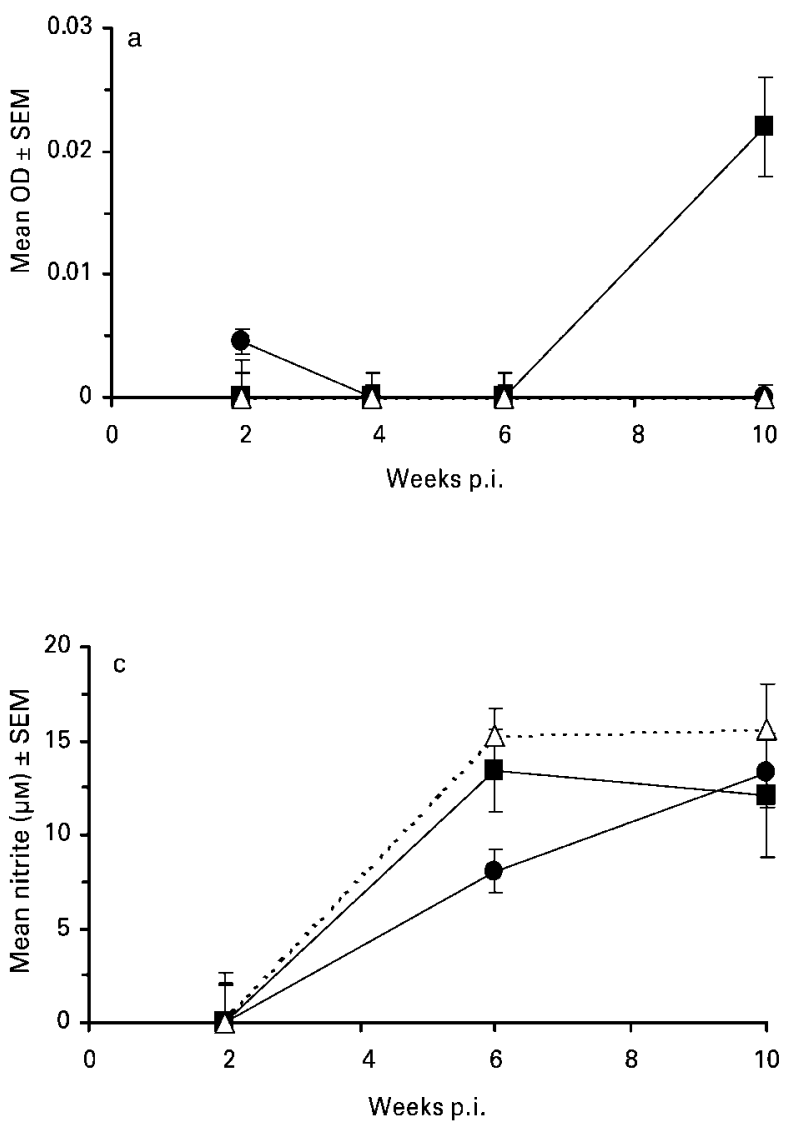

2, $0 \pm 2.14 \mu \mathrm{M}$; week $10,13.35 \pm 1.87 \mu \mathrm{M})$. No significant difference was seen between the peak levels of serum nitrate detected in the three strains, although CBA mice were found to have a significantly slower response $(F=6$, $d f=2, P=0.004$, fig. 2c). In contrast, within intestinal samples, there was a significant difference between the levels of nitrate detected in the three strains of mice $(F=67, d f=2, P<0.001$, fig. $2 \mathrm{~d})$. Little nitrite was detected in SWR mice, although their levels peaked at week 6 p.i to $4.35 \pm 1.59 \mu \mathrm{M}$. In contrast, levels in NIH mice rose from week $2(5.4 \pm 2.12 \mu \mathrm{M})$ to a maximum level at week $6(11.42 \pm 3.0 \mu \mathrm{M})$, which then fell to background levels at week 10 p.i. Nitrate titres in CBA mice fell to background levels at week 4 p.i. from $5.11 \pm 1.62 \mu \mathrm{M}$ at week 2 and then rose again to peak at week 10 p.i. $(8.82 \pm 1.5 \mu \mathrm{M})$.

\section{Experiment 2: rapid, fast and slow expelling infections}

In this set of experiments, three strains representing 'rapid' ((SWR $\left.\times \mathrm{SJL}_{1} \mathrm{~F}_{1}\right)$, 'fast' (SWR) and 'slow' $(\mathrm{C} 57 \mathrm{BL} / 10)$ responder strains of mice were examined for their response phenotype to a primary infection with 100 L3. The worm recoveries over a six week experimental
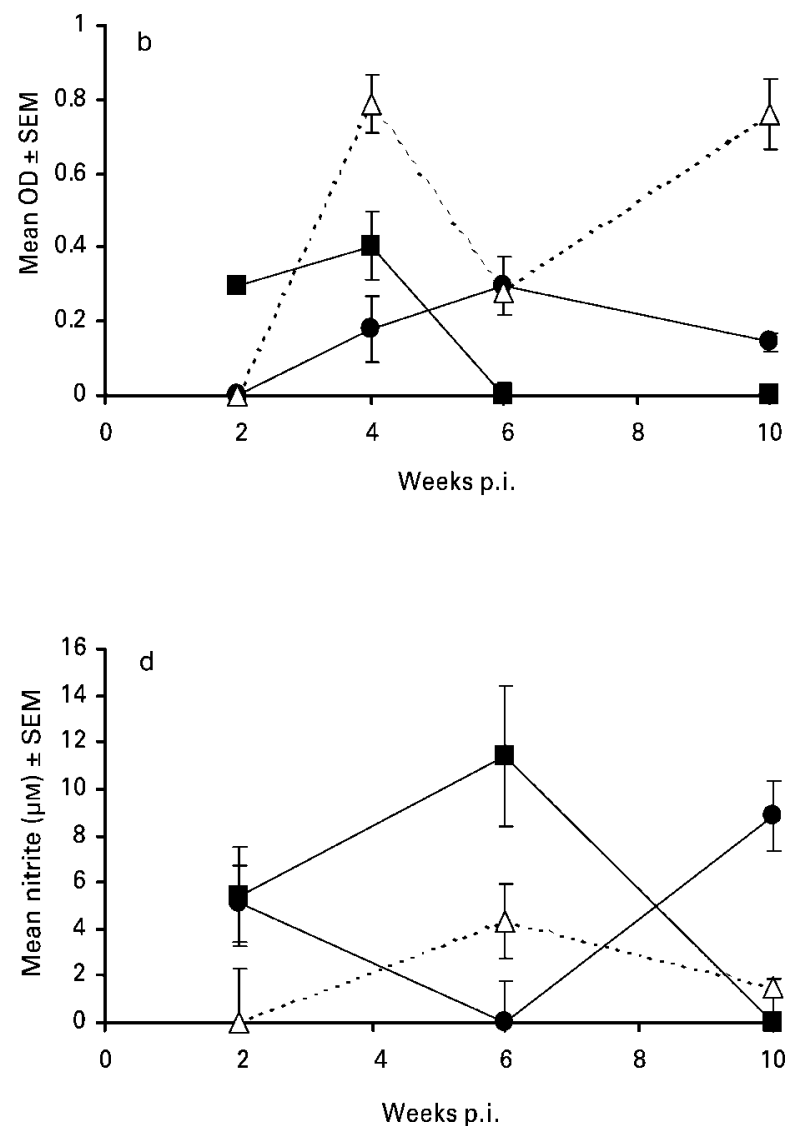

Fig. 2. Experiment 1. Parasite-specific serum (a) and intestinal (b) IgG2a and nitrite in the serum (c) and intestinal fluids (d) of 'fast' responder $($ SWR $\triangle$ ), 'intermediate' responder (NIH $\mathbf{a})$ and 'slow' responder (CBA - ) strains of mice after a primary infection with 50 L3 larvae of Heligmosomoides polygyrus. IgG2a results are presented as mean optical density units (OD) of the infected minus naïve animals; nitrite levels are expressed as mean $\mu \mathrm{M}$ of infected minus naïve animals for each group. 
period are shown in fig. 3a. The 'rapid' responder $\left((\mathrm{SWR} \times \mathrm{SJL}) \mathrm{F}_{1}\right)$ strain quickly expelled their worms within 6 weeks, whereas worm burdens were maintained by the 'slow' responder C57BL/10 mice over this period. In the 'fast' responder SWR mice, however, an unexpectedly small decline in parasite burden occurred by week 6 p.i. $(<14 \%)$, although greater expulsion may have been predicted to occur if the experiment had been continued until week 8 p.i. Statistical analysis showed that the differences observed in expulsion were significant with respect to both the strain and the kinetics of expulsion (strain: $\chi^{2}=325, d f=2, P<0.001 ;$ time: $\chi^{2}=13.45$, $d f=2, P=0.005$ ) (fig. 3a).

Serum MMCP-I levels were already raised by week 2 p.i. in both the $(S W R \times S J L) F_{1}\left(0.78 \pm 0.13 \mu \mathrm{g} \mathrm{ml}^{-1}\right)$ and SWR $\left(1.04 \pm 0.10 \mu \mathrm{g} \mathrm{ml}^{-1}\right)$ mice, peaking at week 4 (F1: $1.32 \pm 0.16 \mu \mathrm{g} \mathrm{ml}^{-1}$; SWR: $1.41 \pm 0.06 \mu \mathrm{g} \mathrm{ml}^{-1}$ ) and then declining slightly by week 6 p.i. (fig. $3 \mathrm{~b}$ ). Overall, there was no significant difference between the levels of serum MMCP-I in the 'fast' responder compared to the 'rapid' responder mice. In the 'slow' responder (C57BL/10) mice, MMCP-I levels also rose slightly by week 4 p.i. (to $0.24 \pm 0.08 \mu \mathrm{g} \mathrm{ml}^{-1}$ ) and were maintained by week 6 p.i., but were very much lower than in either of the other two strains examined (fig. 3b). There was a significant statistical difference in the level and kinetics of serum MMCP-I secretion between the fast and slow responder stains of mice (strain: $F=66, d f=2, P<0.001$; time: $F=8, d f=2, P=0.001$ ) (fig. $3 b$ ). The pattern of secretion of luminal MMCP-I was similar to that of the serum, although MMCP-I titres increased at week 6 p.i. in SWR mice (from $0.21 \pm 0.03 \mu \mathrm{g} \mathrm{mg}^{-1}$ protein at week 4 to $0.26 \pm 0.02 \mu \mathrm{g} \mathrm{mg}^{-1}$ protein at week 6) and declined in $(S W R \times S J L) F_{1}$ mice (from $0.20 \pm 0.04 \mu \mathrm{g} \mathrm{mg}^{-1}$ protein at week 4 to $0.14 \pm 0.06 \mu \mathrm{g} \mathrm{mg}^{-1}$ protein at week 6; fig. 3c). Again, levels of MMCP-I were significantly lower in the 'slow' compared to the 'rapid' and 'fast' responder strains of mice $(F=29, d f=2, P<0.001)$.

With regard to specific serum IgE, levels rose rapidly in $(\mathrm{SWR} \times \mathrm{SJL}) \mathrm{F}_{1}$ mice, peaking at week $4(\mathrm{RRI}=52.19 \pm$ 5.53) and then declining by week 6 p.i. (RRI $=22.41 \pm$ 5.87), whereas IgE levels in SWR mice rose less dramatically but were still increasing by week 6 p.i. (week 4, RRI $=16.61 \pm 5.0$; week 6, RRI $=40.95 \pm 12.67$; fig. 3d). In C57BL/10 mice, there was a significantly slower rise in $\operatorname{IgE}$ levels $(F=7, d f=2, P=0.003)$, with levels rising from basal at week 2 to an index of $8.86 \pm$ 2.37 at week 4 p.i. which was then maintained at week 6 p.i., but were lower than levels seen in the 'rapid' and 'fast' responder strains (fig. 3d). A similar pattern of response was reflected in intestinal IgE levels, except that levels in the $\mathrm{F}_{1}$ hybrid mice were maintained at week 6 p.i. (fig. 3e). There was significant difference with regard to strain and kinetics in the levels of intestinal $\mathrm{IgE}$ observed (strain: $F=3, d f=2, P=0.048$; time: $F=13, d f=2$, $P<0.001)$.

Serum IgG2a levels followed a similar pattern of production in both $(\mathrm{SWR} \times \mathrm{SJL}) \mathrm{F}_{1}$ and $\mathrm{C} 57 \mathrm{BL} / 10$ mice, rising from basal levels at week 2 p.i., peaking at week 4 (OD in $F_{1}$ hybrid, $0.03 \pm 0.002$; OD in C57BL/10, $0.02 \pm 0.005)$ and then declining to control levels at week 6 p.i. (fig. $4 a$ ). Levels in the $F_{1}$ hybrid mice were, however, greater than in C57BL/10 mice at week 4 p.i.
SWR mice, in contrast, showed a small decline in IgG2a levels between weeks 2 and 4 p.i. (OD at week 2, $0.01 \pm$ 0.001 ; OD at week $4,0.005 \pm 0.002$ ), then rose markedly to week $6(0.04 \pm 0.009$, fig. $4 a)$. The differences in both the levels and kinetics of serum IgG2a among the three strains of mice were found to be statistically significant (strain: $F=138, d f=2, P<0.001$; time: $F=100, d f=2$, $P<0.001$ ). An increase in intestinal IgG2a levels was observed in the $F_{1}$ hybrid mice between weeks 2 and 6 p.i., mirroring a similar, albeit smaller, rise in SWR mice. Levels in C57BL/10 titres conversely, fell slightly over this period (fig. 4b). None of these differences in intestinal IgG2a levels reached statistical significance.

In the serum samples, high background levels of nitrite were detected in all the three strains of mice examined such that infection with $H$. polygyrus added no detectable increase in nitrite levels (results not shown). Within the intestine, in comparison to the other strains, levels of nitrite in the 'rapid' responder $\left((\mathrm{SWR} \times \mathrm{SJL}) \mathrm{F}_{1}\right)$ mice increased rapidly throughout the experimental period from a mean level of $3.05 \pm 1.0 \mu \mathrm{M}$ at week 2 p.i., to $17.1 \pm 2.57 \mu \mathrm{M}$ at week 6 p.i. (strain: $F=34, d f=2$, $P<0.001$; time: $F=12, d f=2, P<0.001)$. By contrast, only minimal levels were detected in both the 'fast' responder (SWR) and 'slow' responder (C57BL/10) strains of mice (fig. 4c).

\section{Experiment 3: rapid and fast expelling infections}

In this set of experiments three strains, representing 'rapid' responder $\left((\mathrm{SWR} \times \mathrm{SJL}) \mathrm{F}_{1}\right)$ mice and their respective 'fast' responder parental strains (SWR and SJL) were examined for their response phenotype to a primary infection of $H$. polygyrus. Again, worm recoveries (fig. 5a) did not conform exactly to the expected response pattern, in that, although the $\left(\mathrm{SWR} \times \mathrm{SJL} \mathrm{F}_{1}\right.$ and SJL mice expelled rapidly over $4-6$ weeks p.i. as predicted, worm burdens were maintained in the SWR mice. In spite of this delay in expulsion in the SWR mice, there was a statistically significant difference in the work burdens and kinetics of expulsion among the three strains of mice examined (strain: $\chi^{2}=31, \quad d f=2, \quad P<0.001$; time: $\left.\chi^{2}=45, d f=2, P<0.001\right)$.

MMCP-I serum levels were again raised in $(S W R \times$ SJL) $\mathrm{F}_{1}$ and both parental strains at week 2 p.i. $\left(\mathrm{F}_{1}\right.$ hybrid, $1.09 \pm 0.03 \mu \mathrm{g} \mathrm{ml}^{-1}$; SWR, $1.05 \pm 0.05 \mu \mathrm{g} \mathrm{ml}^{-1}$; SJL, $0.43 \pm 0.02 \mu \mathrm{g} \mathrm{ml}^{-1}$ ), with levels in all three strains peaking at week $4\left(\mathrm{~F}_{1}\right.$ hybrid, $1.14 \pm 0.07 \mu \mathrm{g} \mathrm{ml}^{-1}$; SWR, $1.32 \pm 0.07 \mu \mathrm{g} \mathrm{ml}^{-1}$; SJL, $0.62 \pm 0.06 \mu \mathrm{g} \mathrm{ml}^{-1}$ ) and declining by week 6 p.i. ( $F_{1}$ hybrid, $0.53 \pm 0.09 \mu \mathrm{g} \mathrm{ml} ;^{-1}$ SWR, $\quad 0.79 \pm 0.08 \mu \mathrm{g} \mathrm{ml}^{-1} ; \quad \mathrm{SJL}, \quad 0.38 \pm 0.13 \mu \mathrm{g} \mathrm{ml}^{-1}$ ) (fig. 5b). SJL MMCP-I levels, however, were significantly

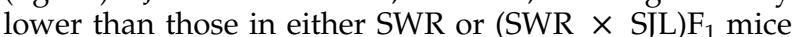
$(F=42, d f=2, P<0.001)$ and could be ranked in order of intensity as SWR $>\mathrm{F}_{1}>\mathrm{SJL}$, although there was no statistical difference between levels in SWR and $F_{1}$ hybrid mice (fig. 5b). A similar pattern of response was observed in the intestinal fluid ((fig. 5c), with levels of MMCP-I significantly lower in SJL mice than SWR or $\mathrm{F}_{1}$ hybrid mice $(F=13, d f=2, P<0.001)$.

Serum IgE levels rose rapidly from basal levels at week 2 in $(\mathrm{SWR} \times \mathrm{SJL}) \mathrm{F}_{1}$ mice and peaked at week 4 p.i. $(\mathrm{RRI}=68.86 \pm 2.36)$ before declining at week 6 p.i. 

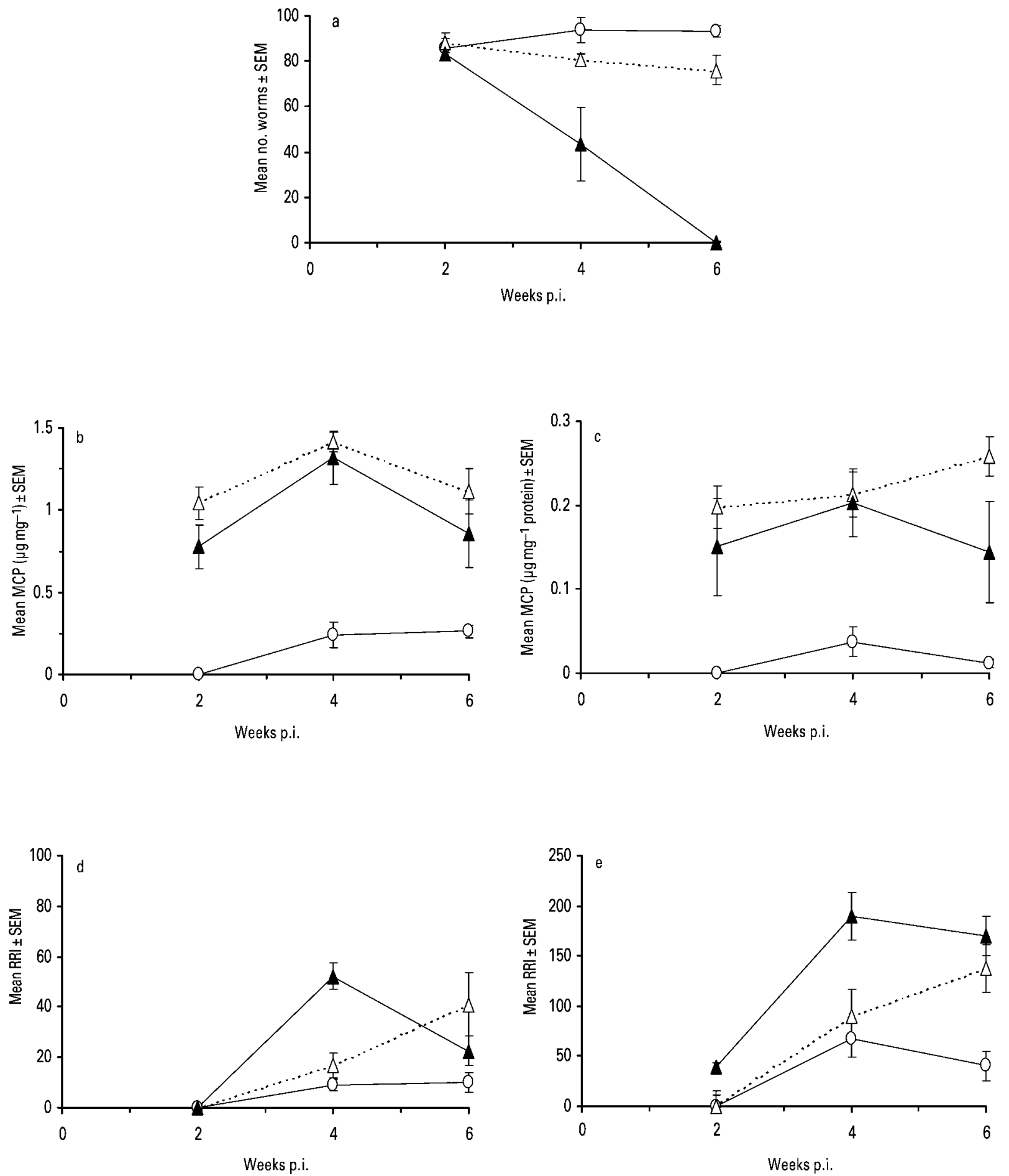

Fig. 3. Experiment 2. Worm burdens (a), serum (b) and intestinal (c) MMCP-I levels and parasite-specific serum (d) and intestinal (e) IgE in 'rapid' responder $\left((\mathrm{SWR} \times \mathrm{SJL}) \mathrm{F}_{1} \mathbf{\Delta}\right)$ ), 'fast' responder $(\mathrm{SWR} \triangle)$ and 'slow' responder $(\mathrm{C} 57 \mathrm{BL} / 10 \mathrm{O})$ strains of mice after a primary infection with $100 \mathrm{~L} 3$ larvae of Heligmosomoides polygyrus. MMCP-I levels are expressed as mean values $\left(\mu \mathrm{g} \mathrm{ml}^{-1}\left(\mathrm{serum}^{\mathrm{m}} \mathrm{or} \mu \mathrm{g} \mathrm{mg}\right.\right.$ protein (intestine)) of the infected minus naïve animals; IgE levels are expressed as mean index relative to naïve and hyper-immune serum (RRI) of infected minus naïve animals. 

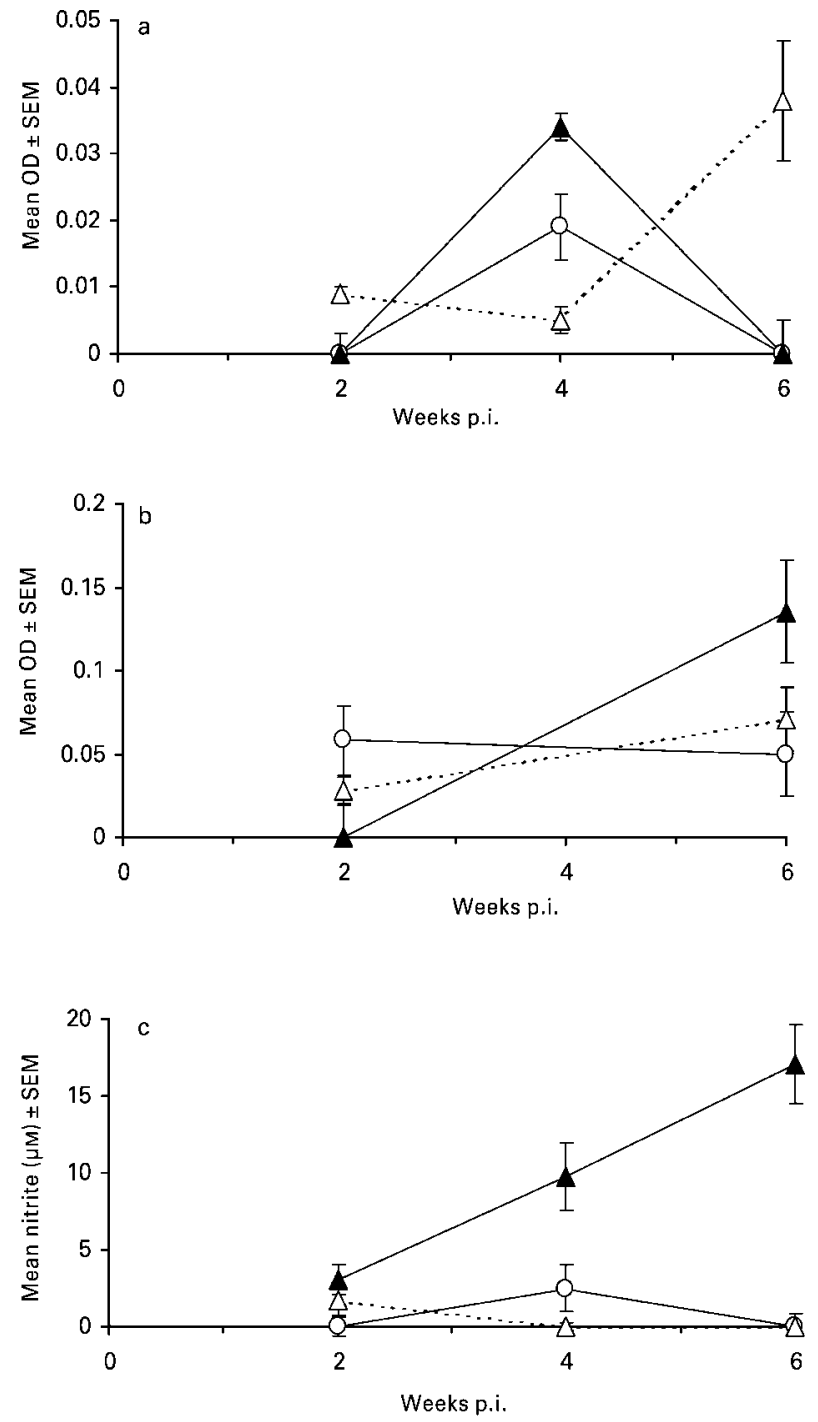

Fig. 4. Experiment 2. Parasite-specific serum (a) and intestinal (b) IgG2a and intestinal nitrite (c) in 'rapid' responder ((SWR $\times$ $\mathrm{SJL}_{1} \mathrm{~F}_{1} \Delta$ ), 'fast' responder (SWR $\triangle$ ) and 'slow' responder $(\mathrm{C} 57 \mathrm{BL} / 10 \mathrm{O})$ strains of mice after a primary infection with 100 L3 larvae of Heligmosomoides polygyrus. IgG2a results are presented as mean optical density units (OD) of the infected minus naïve animals; nitrite levels are expressed as mean $\mu \mathrm{M}$ of infected minus naïve animals for each group.

$(R R I=43.36 \pm 4.18$; fig. $5 d)$. A slower rise in serum $\operatorname{IgE}$ was observed in SWR mice at week $4(\mathrm{RRI}=32.34 \pm$ 6.56), which was continued at week $6(\mathrm{RRI}=82.75 \pm$ 13.47). Levels of specific IgE were significantly lower in SJL mice over this period, never reaching greater than an index of $8(F=13, d f=2, P<0.001$; fig. $5 d)$. In the intestinal samples a similar pattern of response was observed; IgE levels rose sharply above background by week 4 (to an index of $154.79 \pm 11.04$ ) in the (SWR $\times$ $\mathrm{SJL}) \mathrm{F}_{1}$ mice then declined at week 6 (to an index of $121.81 \pm 33.81)$, while in SWR mice, IgE titres increased more slowly $(R R I=51.49 \pm 20.98$ at week 4$)$ and continued to increase by week $6(R R I=192.33 \pm$ 24.63). The levels of specific mucosal IgE in SJL mice, however, remained minimal and were again significantly lower than those observed among the other two strains of mice $(F=11, d f=2, P<0.001$; fig. 5e).

IgG2a responses in serum samples of SWR mice were significantly different from those observed among the other strains of mice $(F=11, d f=2, P<0.001)$ and showed a marked rise at weeks 4 and 6 p.i., with levels at week 6 greater than those observed among the other two strains of mice (OD at week 6: SWR $=0.17 \pm 0.03$; SJL $=$ $0.02 \pm 0.01 ; F_{1}=0.06 \pm 0.02$, fig. 6a). Levels in (SWR $\times$ $\mathrm{SJL}) \mathrm{F}_{1}$ mice rose steadily but more slowly than in the SWR mice, whereas levels in SJL mice dropped from week 2 $(\mathrm{OD}=0.06 \pm 0.01)$ to minimal values by week 6 p.i. (fig. 6a). Levels of luminal IgG2a again showed a sharp increase in SWR mice, with levels in the $F_{1}$ hybrids rising to week 4 p.i. and maintained at week 6 p.i.; SJL mice produced only minimal levels of parasite-specific serum IgG2a (fig. 6b). Again, there was significant statistical difference in the levels and also the kinetics of IgG2a observed among the three strains of mice (strain: $F=17$, $d f=2, P<0.001$; time: $F=9, d f=2, P=0.001$ ).

Within sera, significantly greater levels of nitrite were detected in $(\mathrm{SWR} \times \mathrm{SJL}) \mathrm{F}_{1}$ samples at all times after infection compared to SWR and SJL mice, peaking at week 6 p.i. $(23.57 \pm 3.53 \mu \mathrm{M} ; F=4, d f=2, P=0.048)$. Levels in SJL mice rose from background at week 2 p.i. to peak at week 6 p.i. $(11.45 \pm 5.33 \mu \mathrm{M})$, whereas levels in SWR mice rose from basal at week 2 to peak values at week $4(6.93 \pm 1.16 \mu \mathrm{M})$ and were then maintained at week 6 p.i. (fig. 6c). In intestinal secretions, levels of nitrite rose markedly in both $\mathrm{SJL}$ and $(\mathrm{SWR} \times \mathrm{SJL}) \mathrm{F}_{1}$ mice at week 4 (SJL, $\left.14.45 \pm 2.38 \mu \mathrm{M} ; \mathrm{F}_{1}, 13.33 \pm 0.98 \mu \mathrm{M}\right)$ and then fell at week 6 p.i. (SJL, $\left.5.38 \pm 1.41 \mu \mathrm{M} ; \mathrm{F}_{1}, 12.41 \pm 1.17 \mu \mathrm{M}\right)$. Levels of nitrite detected in SWR mucosal samples were low throughout the infection period (fig. 6d). There was significant statistical difference with regard to level and kinetics of luminal nitrite observed between the three strains of mice (strain: $F=14, d f=2, P<0.001$; time: $F=17, d f=2, P<0.001)$.

In summary, the results of the three experiments suggest that $H$. polygyrus infection in 'slow' responder strains such as CBA and C57BL/10 stimulates neither a Th1 (as assessed by intestinal IgG2a and NO) nor a Th2 (as assessed by intestinal MMCP-I and IgE) response. The 'intermediate' responder strain, NIH, however, are capable of generating both responses (as assessed by intestinal IgE and NO). 'Fast' responder SJL mice, produce minimal IgE and MMCP-I responses and very little IgG2a, but show a rapid and strong intestinal $\mathrm{NO}$ reaction. On the other hand, SWR mice, also 'fast' responders, exhibit high MMCP-I and IgE responses but low NO reactions to the parasite. The 'rapid' responder $(\mathrm{SWR} \times \mathrm{SJL}) \mathrm{F}_{1}$ hybrids in contrast show both strong Th1 and Th2 effector responses in terms of MMCP-I, specific IgE and NO production, to a primary infection with $H$. polygyrus.

\section{Discussion}

Heligmosomoides polygyrus is believed to give rise to chronic infections in mice by the release of immunomodulatory factors that down-regulate $\mathrm{T}$ cell responses 

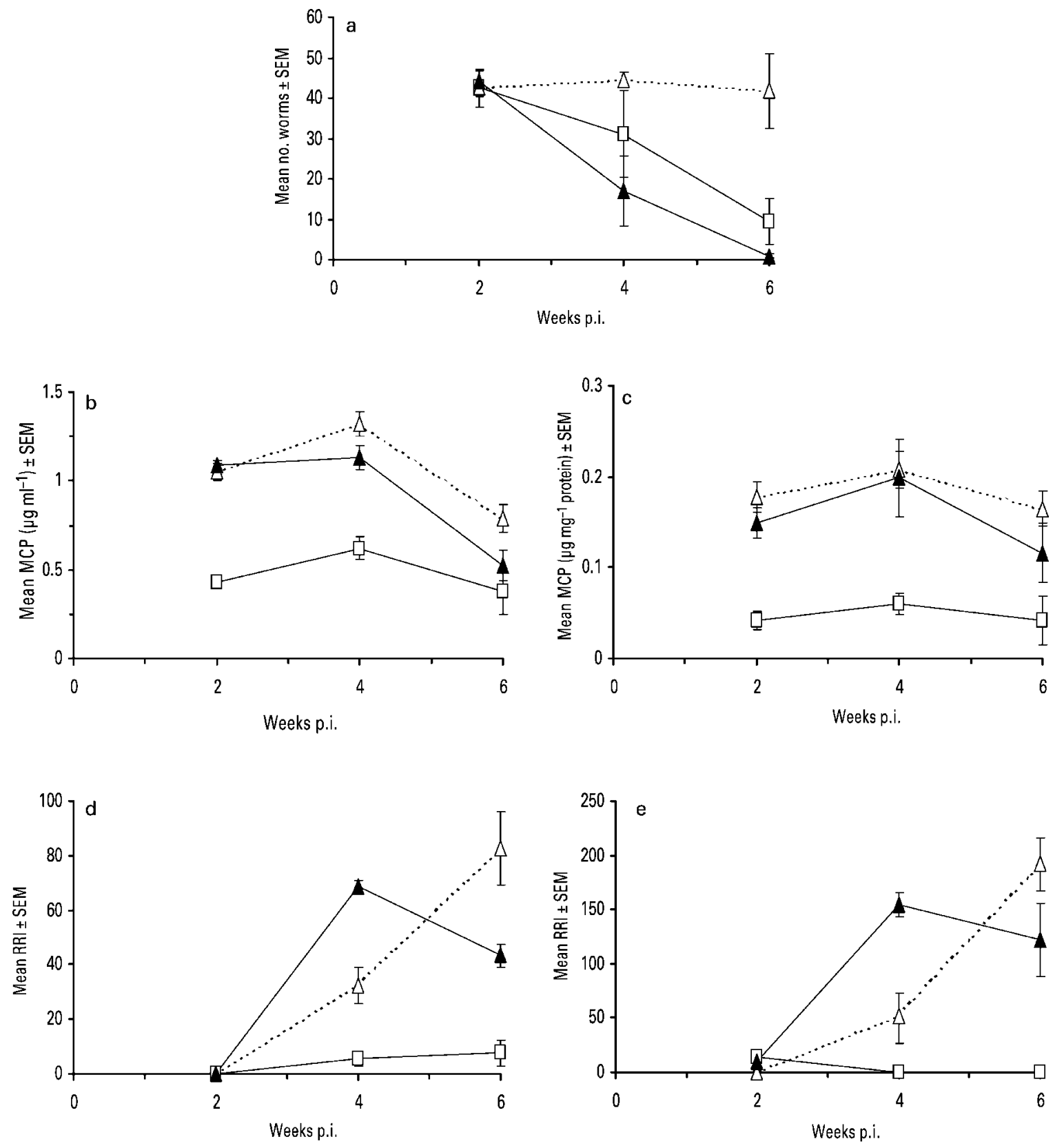

Fig. 5. Experiment 3. Worm burdens (a), serum (b) and intestinal (c) MMCP-I levels and parasite-specific serum (d) and intestinal (e) IgE in 'fast' responder parental strains SWR $(\triangle)$ and SJL $(\square)$ and their 'rapid' responder $F_{1}$ hybrid strain $(\mathbf{\Lambda})$ of mice after a primary infection with $50 \mathrm{~L} 3$ larvae of Heligmosomoides polygyrus. MMCP-I levels are expressed as mean values ( $\mu \mathrm{g} \mathrm{ml}^{-1}$ (serum) or $\mu \mathrm{g} \mathrm{mg} \mathrm{g}^{-1}$ protein (intestine)) of the infected minus naïve animals; IgE levels are expressed as mean index relative to naïve and hyper-immune serum (RRI) of infected minus naïve animals.

which promote the development of Th2-associated reactions such as mucosal mastocytosis and eosinophilia (Behnke, 1987; Dehlawi et al., 1987; Dehlawi \& Wakelin, 1988). In spite of such effects, some inbred strains of mice are still able to expel the parasite within a relatively short period of time after infection, which in part undoubtedly reflects genetic influences upon the host response to parasite-mediated suppression (Behnke et al., 2000).
This study was undertaken to assess the relative roles of Th2-associated immediate and Th1-associated delayed hypersensitivity responses in resistance to infection with $H$. polygyrus and to look for evidence of differential modulation of these $\mathrm{T}$ cell-mediated reactions within such inbred strains following parasitemediated immunosuppression.

In this study, mast cell protease levels in sera and luminal secretions, as a marker of a Th2-associated 

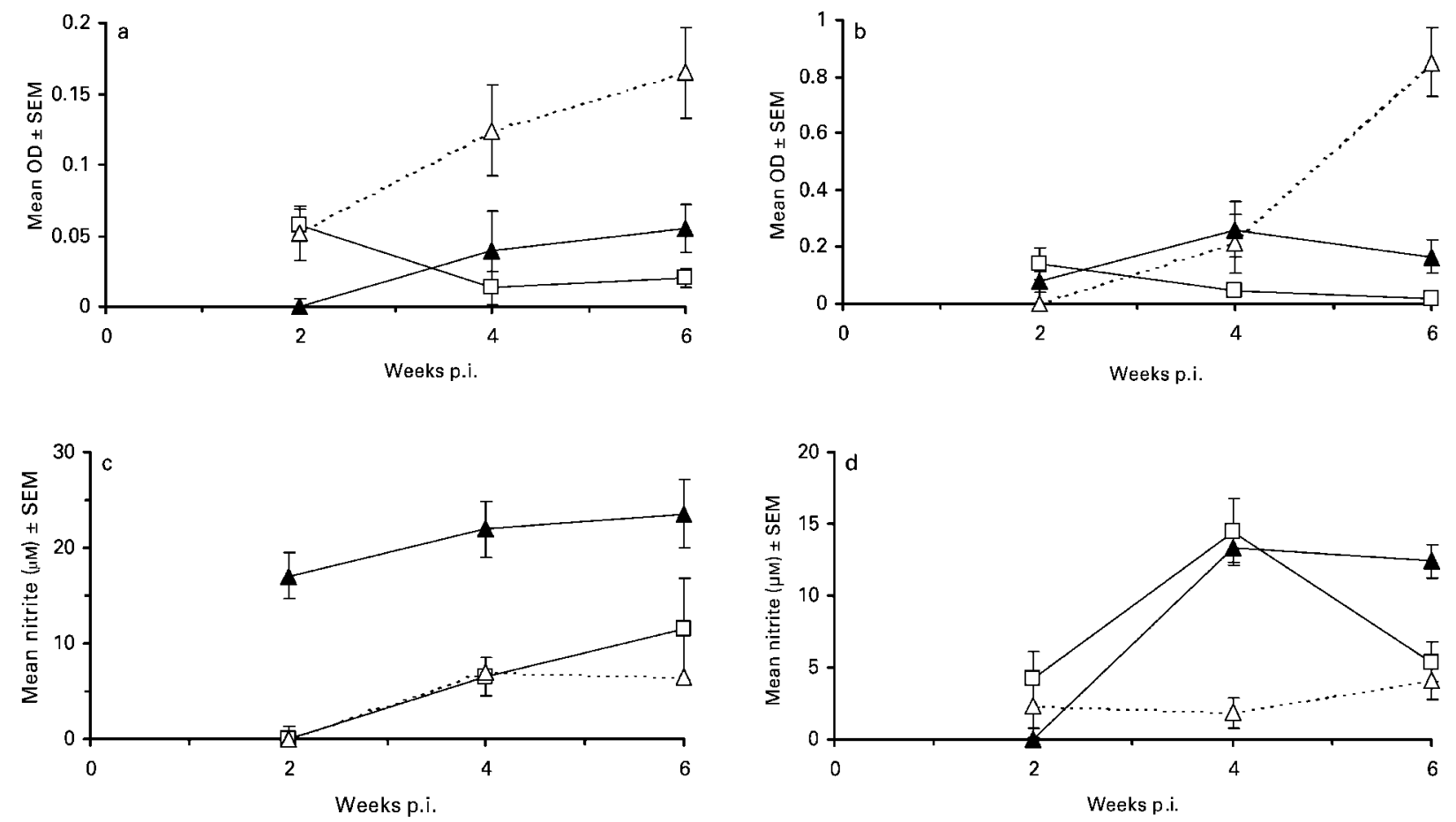

Fig. 6. Experiment 3. Parasite-specific serum (a) and intestinal (b) IgG2a and nitrite in the serum (c) and intestinal fluids (d) of 'fast' responder parental strains SWR $(\triangle)$ and SJL $(\square)$ and their 'rapid' responder $F_{1}$ hybrid strain $(\mathbf{\Lambda})$ of mice after a primary infection with 50 L3 larvae of Heligmosomoides polygyrus. IgG2a results are presented as mean optical density units (OD) of the infected minus naïve animals; nitrite levels are expressed as mean $\mu \mathrm{M}$ of infected minus naïve animals for each group.

immediate hypersensitivity response, were generally shown to exhibit a temporal association with worm expulsion. In $(\mathrm{SWR} \times \mathrm{SJL}) \mathrm{F}_{1}$ mice, the level of mast cell protease peaked at week 4 p.i. which correlated with the onset of expulsion while 'slow' responder strains CBA and C57BL/10 produced consistently low levels of MMCP-I. There was a notable exception to this general pattern in that in the 'fast' responder strain SJL, rapid worm expulsion was observed where little or no MMCP-I release was detected in either serum or intestinal fluids. Therefore, overall, the MMCP-1 results obtained in this study support a role for a Th2 inflammatory response being involved in immunity to a primary infection with $H$. polygyrus in most of the strains examined although this appears to be a straindependent response.

The induction of intestinal $\operatorname{IgE}$ has been proposed to be an important protective mechanism against certain gastrointestinal nematodes particularly those that penetrate the duodenum mucosa, such as Strongyloides venezuelensis, T. spiralis and H. polygyrus (Negrao-Correa, 2001). However, the prevailing theory is that $\operatorname{IgE}$ is not thought to play a major role in immune worm expulsion as IgE deficient mice have been reported to be capable of expelling their worms (Onah \& Nawa, 2000). In addition, treatment of $H$. polygyrus-infected mice with an antimouse IgE $\mathrm{mAb}$ was also found not to inhibit protective immunity (Urban et al., 1992). From the results presented in this study, the role of $\operatorname{IgE}$ in the expulsion of $H$. polygyrus remains equivocal although in 'fast' responder SWR mice, primary infection always resulted in a strong specific IgE response. However, in two out of the three experiments performed, with this strain they failed to expel their worms within 6 weeks p.i. in spite of a marked IgE response. In contrast, SJL, another 'fast' responder strain, also expelled their worms rapidly, but in the virtual absence of a specific IgE response. NIH mice, classed as 'intermediate' responders, however also produced high IgE levels comparable to those of the SWR mice, but generally expelled their worms later than the SWR mice. Interestingly, the 'rapid' expelling hybrid of the two 'fast' expelling parental strains, (SWR $\times$ $\mathrm{SJL}) \mathrm{F}_{1}$, also produced a strong specific $\operatorname{IgE}$ response which temporally correlated with expulsion whereas both 'slow' expelling strains, CBA and C57BL/10, mounted only poor specific IgE responses. The data suggest that the relative importance of any specific $\operatorname{IgE}$ response like the MMCP-1 response is also strain-dependent.

In mice, where NO was detected using the Griess reagent method, higher levels of nitrite were found in the mucosal washings of infected mice than in sera. This suggests that NO is produced locally and may have a role in the mucosal immune response to infection with $H$. polygyrus. Moreover, serum titres of nitrite did not mirror mucosal levels, possibly attributable to high concentrations of naturally occurring nitrate in blood masking the kinetics of local NO production in the gut in response to infection. In addition, high levels of mucosal nitrite, hence $\mathrm{NO}$, were also associated with both 'rapid' $\left((\mathrm{SWR} \times \mathrm{SJL}) \mathrm{F}_{1}\right)$ and certain 'fast' responder $(\mathrm{SJL})$ strains 
of mice. In this study, relatively high mucosal levels of NO were detected early in infection in the latter strain, in the virtual absence of either a Th2-associated MMCP-I or specific IgE response, but were also not associated with a comparable Th1-associated specific IgG2a response. Indeed, the general finding from this work was that specific IgG2a responses did not appear to correlate with either worm expulsion or Th2-associated responses (e.g. MMCP-I) or to other Th1 associated indicators such as serum or mucosal NO production. However, there was a trend for specific IgG2a responses to parallel specific IgE levels in their respective strains, suggesting that such responses are more closely linked with particular genotypes rather than resistance phenotypes of the host strains. This goes against current dogma which suggests that IFN- $\gamma$ and IL- 4 act as reciprocal agents in the determination of IgG2a and IgE isotype switching (Coffman et al.,1988) and lends support to a dual mechanism of Th1 and Th2 responses operating in tandem.

Little nitrite was detected in either the sera or intestinal samples of 'slow' expelling strains, CBA or C57BL/10 suggesting that neither a strong Th2 nor Th1-associated immune response are elicited in these susceptible strains following infection with $H$. polygyrus. The overall mast cell protease/IgE (Th2-associated) and nitric oxide/IgG2a (Th1-associated) responses obtained in this study portray a complex pattern of responses between strains of differing resistance phenotype. These patterns can be interpreted as illustrating that two expulsion mechanisms may be operating in the immune response of certain strains of mice to infection with $H$. polygyrus. In the 'fast' responder, SWR, strain, expulsion appears to be linked to Th2-associated MMCP-1 responses, whereas, in the 'intermediate' responder, NIH, strain, lack of early expulsion appears to be associated with the eliciting of a reciprocal Th1-associated NO response. This latter interpretation is supported by the finding that vaccination of NIH with Freunds' adjuvant appears to stimulate an inhibitory CMI response which acts to inhibit worm expulsion in this strain (Ben-Smith, unpublished observation).

In the 'slow' responder strains of mice, C57BL/10 and CBA, susceptibility appears to reflect both a poor Th2 and a poor Th1 response phenotype. However, unlike SWR, the 'fast' expulsion phenotype of SJL mice is associated with a strong Th1-associated NO response. Moreover, in the 'rapid' expelling $\mathrm{F}_{1}$ hybrid of both 'fast' responder parental strains $\left((\mathrm{SWR} \times \mathrm{SJL}) \mathrm{F}_{1}\right)$ expulsion appeared to correlate with both a strong Th1- (NO) and Th2(MMCP-1) associated responses, suggesting that the $\mathrm{F}_{1}$ hybrid has inherited both mechanisms of immune expulsion from its respective parents which can act synergistically.

Although in this study nitric oxide production is proposed to reflect a Th1-mediated response, the data presented may prove compatible with the current dogma regarding the apparent central role of IL-4 in the control of $H$. polygyrus infection should the NO-associated responses prove to result from IL-4 regulated release of TNF $\alpha$ as has been previously reported for T. spiralis infections (Garside et al., 2000). Alternatively, disruption of epithelial integrity either directly by $H$. polygyrus or indirectly by the induction of a Th2 inflammatory response may allow commensal bacteria to invade the GI tract leading to induction of $\mathrm{TNF} \alpha$ and iNOS as previously reported for Trichuris suis infections (Garside et al., 2000). It would therefore be of interest to repeat these studies utilizing $\mathrm{TNF} \alpha / \mathrm{TNF} \alpha \mathrm{R}$ gene deficient mice and gnotobiotic mice to investigate these latter possibilities. The protective mechanisms involved in the immune expulsion of $H$. polygyrus, therefore remain to be fully characterized.

In conclusion, the data presented in this study would indicate that both Th2- and Th1- associated effector processes may occur in primary $H$. polygyrus infections in mice, resulting in worm expulsion. While expulsion is most commonly associated with a Th2-type pattern of mediator response, in certain strains Th1-type responses predominate and may mediate expulsion. Chronic $H$. polygyrus infections may then result from a general parasite-mediated suppression of both arms of the Th response in susceptible strains.

\section{Acknowledgements}

We would like to express our thanks to Professors D. Wakelin and P.N.R. Usherwood for the provision of the facilities for this study in the Department of Life Science at the University of Nottingham. We are indebted to Mr D. Fox for the excellent care of our animals and to Mrs J. Brown for technical assistance. The work was supported by the MRC through project grant no. G8923735/T to JMB.

\section{References}

Alizadeh, H. \& Wakelin, D. (1982) Genetic factors controlling the intestinal mast cell response in mice infected with Trichinella spiralis. Clinical and Experimental Immunology 49, 331-337.

Artis, D., Potten, C.S., Else, K.J., Finkleman, F.D. \& Grencis, R.K. (1999) Trichuris muris: Host intestinal epithelial cell hyperproliferation during chronic infection is regulated by interferon- $\gamma$. Experimental Parasitology 92, 144-153.

Bancroft, A.J., McKenzie, A.N.J. \& Grencis, R.K. (1998) A critical role for IL-13 in resistance to intestinal nematode infection. Journal of Immunology 160, 3453-3461.

Behnke, J.M. (1987) Evasion of immunity by nematode parasites causing chronic infections. Advances in Parasitology 26, 1-71.

Behnke, J.M. \& Parish, H.A. (1979) Expulsion of Nematospiroides dubius from the intestine of mice treated with immune serum. Parasite Immunology 1, 26-31.

Behnke, J.M. \& Robinson, M. (1985) Genetic control of immunity to Nematospiroides dubius: a 9-day anthelmintic abbreviated immunizing regime which separates weak and strong responder strains of mice. Parasite Immunology 7, 235-253.

Behnke, J.M. \& Wahid, F.N. (1991) Immunological relationships during primary infection with Heligmosomoides polygyrus (Nematospiroides dubius): $\mathrm{H}-2$ linked 
genes determine worm survival. Parasitology 103, 157-164.

Behnke, J.M., Lowe, A., Menge, D., Iraqi, F. \& Waklein, D. (2000) Mapping the genes for resistance to gastrointestinal nematodes. Acta Parasitologica 45, $1-13$.

Coffman, R.L., Seymour, B.W.P., Hudak, S., Jackson, J. \& Rennick, D. (1989) Antibody to interleukin 5 inhibits helminth-induced eosinophilia in mice. Science 245, 308-310.

Crawley, J.M. (1993) GLIM for ecologists. Oxford, Blackwell Scientific Publications.

Dehlawi, M.S. \& Wakelin, D. (1988) Suppression of mucosal mastocytosis by Nematospiroides dubius results from an adult worm-mediated effect upon host lymphocytes. Parasite Immunology 10, 85-95.

Dehlawi, M.S., Wakelin, D. \& Behnke, J.M. (1987) Suppression of mucosal mastocytosis by infection with the intestinal nematode Nematospiroides dubius. Parasite Immunology 9, 187-194.

Elson, C.O., Ealding, W. \& Lefkowitz, J. (1984) A lavage technique allowing repeated measurement of IgA antibody in mouse intestinal secretions. Journal of Immunological Methods 67, 101-108.

Finkelman, F.D., Holmes, J., Katona, I.M., Urban, J.F. Jr, Beckmann, M.P., Park, L.S., Schooley, K.A., Coffman, R.L., Mosmann, T.R. \& Paul, W.E. (1990) Lymphokine control of in vivo immunoglobulin isotype selection. Annual Review of Immunology 8, 303-333.

Finkelman, F.D., Shea-Donohue, T., Goldhill, J., Sullivan, C.A., Morris, S.C., Madden, K.B., Gause, W.C. \& Urban, J.F. Jr (1997) Cytokine regulation of host defense against parasitic gastrointestinal nematodes. Lessons from studies with rodent models. Annual Review of Immunology 15, 505-533.

Garside, P., Kennedy, M.W., Wakelin, D. \& Lawrence, C. (2000) Immunopathology of intestinal helminth infection. Parasite Immunology 22, 605-612.

Gill, H.S., Watson, D.L. \& Brandon, M.R. (1992) In vivo inhibition by a monoclonal antibody to CD4+ T cells of humoral and cellular immunity in sheep. Immunology $77,38-42$.

Green, L.C., Wagner, D.A., Glogowski, J., Skipper, P.L., Wishnok, J.S. \& Tannenbaum, S.R. (1982) Analysis of nitrate, nitrite, and [15N]nitrate in biological fluids. Analytical Biochemistry 126, 131-138.

Grencis, R.K., Else, K.J., Huntley, J.F. \& Nishikawa, S.I. (1993) The in vivo role of stem cell factor (c-kit ligand) on mastocytosis and host-protective immunity to the intestinal nematode Trichinella spiralis in mice. Parasite Immunology 15, 55-59.

Healy, M.J.R. (1988) GLIM: an introduction. Oxford, Clarendon Press.

Huntley, J.F., Gooden, C., Newlands, G.F., Mackellar, A., Lammas, D.A., Tuohy, M., Woodbury, R.G. \& Miller, H.R.P. (1990) Distribution of intestinal mast cell protease in blood and tissues of normal and Trichinella infected mice. Parasite Immunology 12, 85-95.

Jenkins, S.N. \& Behnke, J.M. (1977) Impairment of primary expulsion of Trichuris muris in mice concurrently infected with Nematospiroides dubius. Parasitology 75, 71-78.

Liew, F.Y., Milliott, S., Li, Y., Lelchuk, R., Chan, R. \& Ziltener, H. (1989) Macrophage activation by interferon-gamma from host-protective $\mathrm{T}$ cells is inhibited by interleukin (IL) 3 and IL4 produced by disease-promoting $\mathrm{T}$ cells in leishmaniasis. European Journal of Immunology 19, 1227-1232.

Mossman, T.R. \& Coffman, R.L. (1989) Heterogeneity of cytokine secretion patterns and function of helper $\mathrm{T}$ cells. Advances in Immunology 46, 111-147.

Mossman, T.R. \& Moore, K.W. (1991) The role of IL-10 in crossregulation of Th1 and Th2 responses. Immunology Today 12, A49-A53.

Nakamura, T., Kamogawa, Y., Bottomly, K. \& Flavell, R.A. (1997) Polarisation of IL-4 and IFN $\gamma$-producing CD4+ T cells following activation of naive CD4+ T cells. Journal of Immunology 158, 1085-1094.

Nawa, Y. \& Miller, H.R.P. (1979) Adoptive transfer of intestinal mast cell response in rats infected with Nippostrongylus brasiliensis. Cellular Immunology 42, 225-239.

Negrao-Correa, D. (2001) Importance of immunoglobulin $\mathrm{E}$ (IgE) in the protective mechanism against gastrointestinal nematode infection: looking at the intestinal mucosae. Revista do Instituto de Medicina Tropical Sao Paulo 43, 291-299.

Onah, D.N. \& Nawa, Y. (2000) Mucosal immunity against parasitic gastrointestinal nematodes. Korean Journal of Parasitology 38, 209-236.

Romagnani, S. (1992) Induction of Th1 and Th2 responses: a key role for the 'natural' immune response? Immunology Today 13, 379-381.

Rothwell, T.L.W. (1989) Immune expulsion of parasitic nematodes from the alimentary tract. International Journal for Parasitology 19, 139-168.

Ryan, B.F., Joiner, B.L. \& Ryan, T.A. (1985) Minitab handbook. Duxbury Press, Boston.

Shea-Donohue, T., Sullivan, C., Finkelman, F.D., Madden, K.B., Morris, S.C., Goldhill, J., PineiroCarrero, V. \& Urban, J.F. Jr (2001) The role of IL-4 in Heligmosomoides polygyrus-induced alterations in murine intestinal epithelial cell function. Journal of Immunology 167, 2234-2239.

Tuohy, M. (1992) Genetic control and cytokine regulation of inflammatory responses to intestinal parasitic infections. PhD thesis, University of Nottingham.

Tuohy, M.B., Lammas, D.A., Wakelin, D., Huntley, J.F., Newlands, G.F. \& Miller, H.R.P. (1990) Functional correlations between mucosal mast cell activity and immunity to Trichinella spiralis in high and low responder mice. Parasite Immunology 12, 675-685.

Urban, J.F., Katona, I.M., Paul, W.E. \& Finkelman, F.D. (1991) Interleukin 4 is important in protective immunity to a gastrointestinal nematode infection in mice. Proceedings of the National Academy of Sciences, USA 88, 5513-5517.

Urban, J.F., Madden, K.B., Svetic, A., Cheever, A., Trotta, P.P., Guuse, W.C., Katona, I.M. \& Finkelman, F.D. (1992) The importance of Th2 cytokines in 
protective immunity to nematodes. Immunological Reviews 127, 205-219.

Wahid, F.N. \& Behnke, J.M. (1993) Immunological relationships during primary infection with Heligmosomoides polygyrus (Nematospiroides dubius): parasite specific IgG1 antibody responses and primary response phenotype. Parasite Immunology 15, 401-413.

Wahid, F.N., Robinson, M. \& Behnke, J.M. (1989)

Immunological relationships during primary infection with Heligmosomoides polygyrus (Nematospiroides dubius): expulsion of adult worms from fast responder syngeneic and hybrid strains of mice. Parasitology 98, 459-469.

Wakelin, D. (1993) Allergic inflammation as a hypothesis for the expulsion of worms from tissues. Parasitology Today 9, 115-116.

(Accepted 10 February 2003)

(c) CAB International, 2003 